\title{
DIE LEWE VAN JOAO ALBASINI
}

Mev W.J. Kleyn*

\section{The article below relates the story of the Portuguese Joao Albasini, known as Juwawa, who was one of the first Europeans to take up residence in the eastern bushveld.}

Geskiedenis het deur die eeue heen bewys dat ontdekkingsreise direk met Portugese seevaarders soos Prins Hendrik die Seevaarder, Vasco da Gama, Columbus en Bartolomeu Dias geassosieer word. Belangrike baanbrekerswerk is wêreldwyd deur dié groot manne verrig. Latere jare het 'n minder bekende jong Portugese avonturier, Joao Albasini, ook diep spore op SuidAfrikaanse bodem getrap.

Die seun van 'n skeepskaptein is in 1813 op 'n skip in die hawe van Lissabon gebore. Joao was van kindsbeen af bewus van die onkeerbare avontuurlus wat in sy are gebruis het om nuwe horisonne te verken. Op negentienjarige ouderdom kry hy vir die eerste keer die geleentheid om daaraan uiting te gee toe hy sy vader en broer op 'n handelsreis na Oos-Afrika moes vergesel.

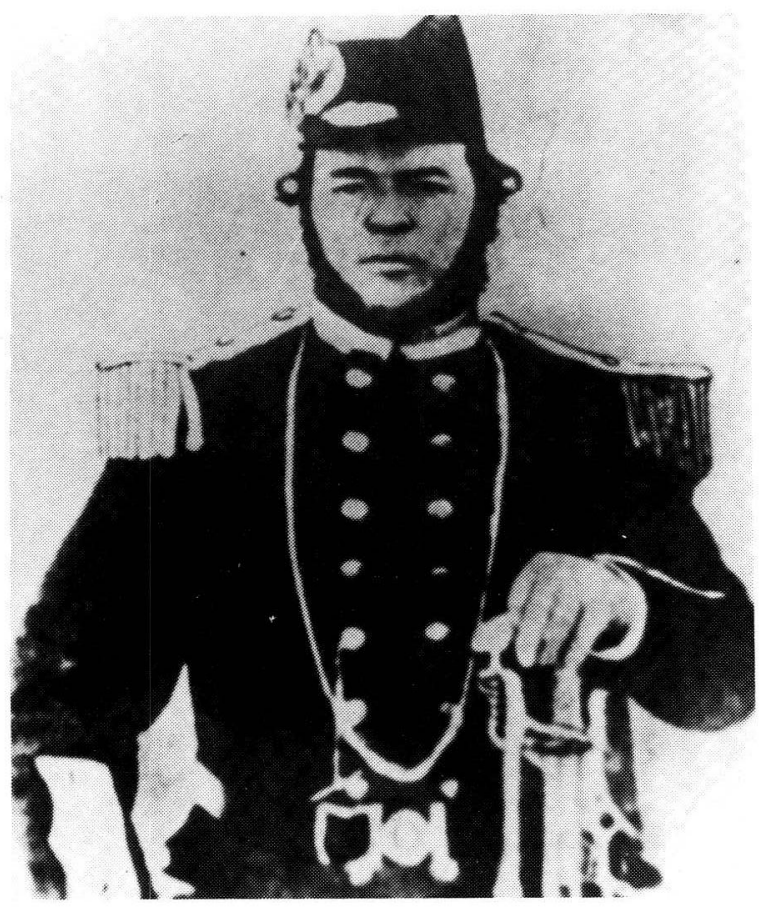

João A/basini bekend as Juwawa, was een van dle eerste Europeërs wat hom in die Oos-Transvaalse Bosveld gevestig het

Hy is in 1950 getroud met Gertina van Rensburg en het in Lydenburg gewoon tot 1853. Hy het hom in die Voortrekkerdorp Schoemansdal hervestig
Die doel van dié reis was om handelsroetes van Lourenco Marques (destyds Delagoabaai) na die binneland te open. Dit was dus noodsaaklik om 'n handelspos by Delagoabaai op te rig. 'n Opgewonde Joao Albasini het in Delagoabaai agtergebly om beheer oor die handelspos uit te oefen.

Dit het gou geblyk dat die jong Albasini nie 'n tekort aan avonture sou ondervind nie. In 1834, word Lourenco Marques deur die Zoeloe Impi's van koning Soshangane binnegeval en geplunder. Al die blanke nedersetters is wreed vermoor behalwe Albasini, wat hom as kranksinnig voorgedoen het en deur die Zoeloes na hul stat ontvoer is. Hy slaag egter daarin om na ses maande te ontsnap en bevind hom in die binneland, noord van Lourenco Marques, waar hy as jagter en ivoorhandelaar ' $n$ bestaan gemaak het. In sy hoedanigheid as handelaar en jagter was hy ook in die posisie om latere jare die Voortrekkers van lewensmiddele te voorsien.

In 1840 besluit hy om verder die binneland in te trek op soek na nuwe jagvelde. Gedurende sy omswerwinge maak hy kennis met talle swart stamme waar hy groot respek afgedwing het en die bynaam "Juwawa" gekry het.

In 1845 vestig hy hom op 'n stuk land op die walle van die Sabierivier wat hy van die Opperhoof Magashula verkry het. Hy rig hier ook 'n handelspos op en word daardeur een van die eerste blanke nedersetters in die bosveldstreek van die Oos-Transvaal.

Latere jare het hy hom op die plaas Rustplaats naby Ohrigstad gevestig waar hy as handelaar 'n winkel op die dorp begin het. Dit was ook hier in Ohrigstad waar hy sy aanstaande vrou, Gertina van Rensburg, ontmoet het. Sy was die niggie van Lang Hans van Rensburg, leier van 'n ossewatrek wat in 1836 deur 'n swart stam uitgewis is.

Die jong Portugees en boeremeisie het heelwat teenkanting van haar ouers ontvang aangesien Albasini 'n Rooms-Katoliek was en net Portugees en swarttale magtig was. Die kommunika- 
siegaping was egter nie onoorbrugbaar vir die jong paartjie nie, in 1850 is hulle deur landdros J. de Clerq op Lydenburg in die huwelik bevestig. Uit dié huwelik is drie seuns en ses dogters gebore.

Albasini se swerfgees kon egter nie gedemp word nie en in 1853 trek hy, saam met sy swart volgelinge, na die dorp Zoutpansberg (later bekend as Schoemansdal).

Hoewel Albasini weer 'n winkel in die dorp begin het, het hy sy Magwamba-volgelinge op die plaas Goedewensch naby Piesangskop gevestig. In 1857 trek hy egter ook plaas toe waar hy met al die arbeid tot sy beskikking, Goedewensch in 'n spogplaas omskep het. Watervore is oor ' $\mathrm{n}$ afstand van $10 \mathrm{~km}$ na die opstal aangelê, strate is van klip uitgelê en bome en watervore is langs die strate aangebring. Afgesien van die verskeie vrugtesoorte op sy plaas, het hy ook met die aanplant van 'n koffieplantasie begin. Ter beskerming van sy huis en gesin het hy 'n reghoekige skansmuur met skietgate rondom die huis laat bou.

Hierdie "skanz" was later die toevlugsoord vir verskeie mense wat voor die geweld van die Vhavenda moes vlug. Goedewensch was ook welbekend onder reisigers, jagters en staatsmanne soos president M.W. Pretorius. Hier het sy Magwamba-volgelinge hom eenparig as hulle kaptein aanvaar.

Albasini was deurentyd besig om goeie betrekkinge tussen die boere en Portugese gemeenskappe op te bou. Derhalwe is hy in 1858 as die vise-konsul van Portugal in Transvaal aangestel. Dit het teweeggebring dat 'n gereelde maandelikse posdiens tussen Goedewensch en Delagoabaai ingestel is. Bekende Portugese handelaars het ook beplan om ' $n$ pad te bou waarop stoomwaens handelsware na Transvaal kon vervoer.

'n Jaar later het hy superintendent van die swart stamme by Spelonken in die Noord-Transvaal geword. In hierdie tydperk word hulle swaar deur teëspoed getref toe plunderbendes ' $n$ reeks strooptogte uitgevoer het en malaria uitgebreek het. Dit het tot gevolg gehad dat Schoemansdal in Julie 1967 ontruim moes word. Albasini het egter geweier om sy plaas te verlaat. ' $n$ Paar gesinne, wat nie waens gehad het om te trek nie, het by hom aangesluit.

Dit was gou duidelik dat oorlog onvermydelik was. Albasini was gedwing om sy jagters in im-

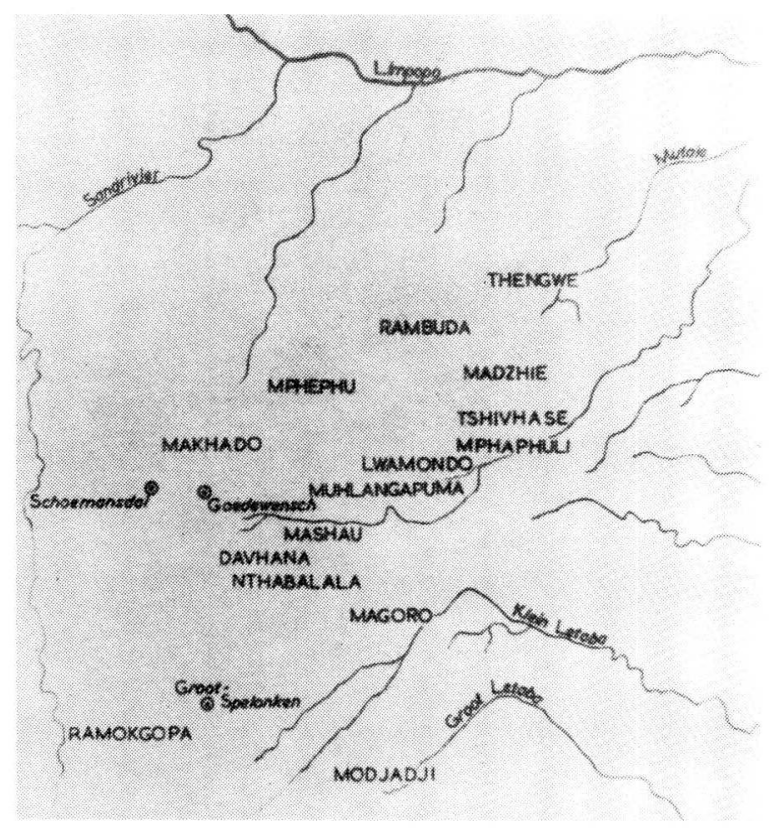

'n Kaart van die Albasini-gebied in die jare 1859-1866

pi's in te deel en slaggereed te maak vir enige voorvalle wat kon plaasvind. Uit pure desperaatheid moes hy later die hulp van hoofgeneraal Wamanunga ingeroep het om 'n teenaanval te loods. Die vyand se bergvestings is op verskeie plekke aangeval, maar Albasini se aartsvyand, Makhado, was onoorwonne. Die voortdurende oorloë met Makhaats het Albasini egter geruïneer. Hy het wel oor voldoende krygers beskik om oorlog met die Vendas te voer, maar sy handelstransaksies het daaronder gely. Hy het ook nie oor die nodige middele beskik om ' $n$ volskaalse oorlog te voer nie.

'n Verdere terugslag was Albasini se ontheffing uit sy pos as superintendent van die swart stamme. Dit het gevolg nadat verskeie klagtes ontvang is dat Albasini hom tydens die stamgevegte wangedra het. Dit het hom egter nie ondergekry nie. Hy het verbete teruggeveg en weer eens die vertroue van die Transvaalse Regering teruggewen deur as Presidentvrederegter vir Kleinspelonken aangestel te word.

Wrywing tussen Albasini en die regering het hom later daartoe gedwing om te bedank as kommissaris in 1875. Die regering het selfs gepoog om hom te arresteer, maar weens teenkanting vanaf sy stam, die Knopneuse, kon hulle nie daarin slaag nie.

Die Britse regering het in 1877 hom verder van sy pos onthef omdat hy klaarblyklik nie vrede tussen die swart stamme kon handhaaf nie. Dit het sake egter nie bevorder nie en onluste het in 
Sekhukhuneland uitgebreek. Dit het tot gevolg gehad dat Albasini op aandrang van 'n aantal swart hoofmanne in sy pos heraangestel is.

Hoewel die Regering baie klagtes teen Albasini gehad het, het hy heelwat goeie dade verrig. In 1879 het hy 'n eenheid van swart krygers in die oorlog teen Sekhukhune beskikbaar gestel. Hy het later ook Sir Theophilus Shepstone se vertroueling geword en Sir Shepstone het veral op Albasini staatgemaak om 'n sukses van die nuwe belastingbeleid vir swartmense te maak.

Albasini het egter sy laaste jare in groot armoede op sy plaas Goedewensch deurgebring. Hoewel hy voortgegaan het om die regering te dien as Presidentvrederegter en lid van die distriksraad, het sy kragte vinnig ingegee. Op 74jarige ouderdom het hy ' $n$ ernstige beroerteaanval gehad wat veroorsaak het dat hy sy laaste lewensjare in die bed moes deurbring.

Sy getroue volgelinge onder die swart stamme het egter nie van hom vergeet nie. Hulle het gereeld besoek afgelê en hul avonture uit die verlede herleef.

Joao "Juwawa" Albasini het ' $n$ vol lewe gely wat deurweef was met talle avonture. Op 10 Julie

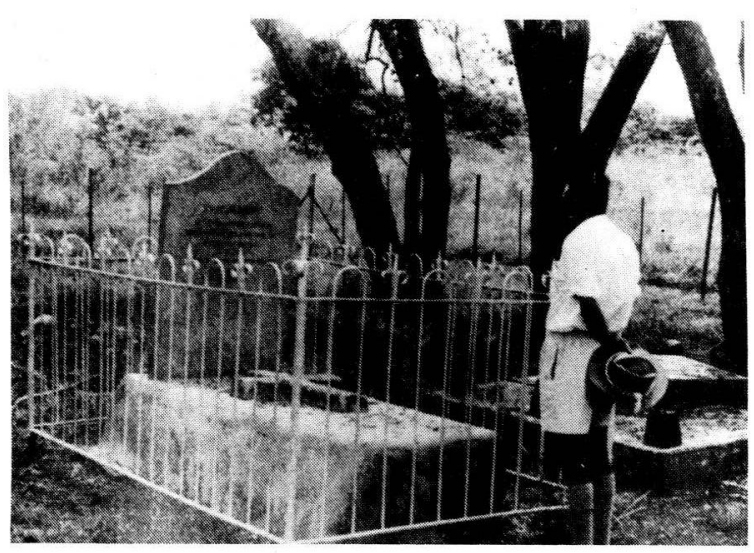

Mnr João Albasini by sy oupa se graf op die plaas Goedewensch

1888 is sy lewenslig uitgeblaas en is hy op sy geliefde plaas Goedewensch begrawe. Die Maghambavolk was in diepe rou gehul en het by sy begrafnis hul laaste eerbewys getoon deur die dag met sononder die koningsgroet uit te bulder: "Bayette!"

${ }^{*}$ Mer W.J. Kleyn, Dip Joernalistiek

\section{BIBLIOGRAFIE}

1. Bantu, Augustus 1972, Deel XIX, W. 8

2. Dictionary of South African Biography, Vol II, p. 5. 